\title{
Ethological problems and learning disability due to aluminium toxicity in rats
}

\author{
Amira A. Goma ${ }^{1}$, Usama E. Mahrous ${ }^{2}$ \\ ${ }^{1}$ Dept. of Animal Husbandry and wealth development, Faculty of Veterinary Medicine, Alexandria University, Egypt \\ ${ }^{2}$ Dept. of Animal Husbandry and wealth development, Faculty of Veterinary Medicine, Damanhour University, Egypt
}

\section{Email address:}

babytuota2005@yahoo.com (A. A. Goma), usama 1966@damanhour.edu.eg (U. E. Mahrous)

\section{To cite this article:}

Amira A. Goma, Usama E. Mahrous. Ethological Problems and Learning Disability Due to Aluminum Toxicity in Rats, Animal and Veterinary Sciences. Vol. 1, No. 2, 2013, pp. 12-17. doi: 10.11648/j.avs.20130102.11

\begin{abstract}
A total of 35 Sprague-Dawley adult rats were used to investigate the effect of aluminum toxicity on behavioral patterns of adult female rats and learning ability of offspring. Rats were allotted into 4 groups, group one received $2 \mathrm{~g} / \mathrm{l}$ anhydrous aluminum chloride $(n=10)$, group two received $3 \mathrm{~g} / 1$ anhydrous aluminum chloride $(\mathrm{n}=10)$, group thr.ee received $3.5 \mathrm{~g} / \mathrm{l}$ anhydrous aluminum chloride in drinking water $(\mathrm{n}=10)$ and control group did not receive anhydrous aluminum chloride $(n=5)$ from 8 th day of pregnancy till weaning of pups. The obtained results showed that feeding time increased significantly in $2 \mathrm{~g} / \mathrm{l}$ and $3.5 \mathrm{~g} / \mathrm{l}$ anhydrous aluminum chloride groups than control one, while, litter licking frequency and nursing time increased significantly in $2 \mathrm{~g} / \mathrm{l}$ anhydrous aluminum chloride than other groups. On contrary lying time decreased significantly in rats treated with $2 \mathrm{~g} / 1$ anhydrous aluminum chloride than other groups, licking and scratching decreased in $3 \mathrm{~g} / 1$ and $3.5 \mathrm{~g} / 1$ anhydrous aluminum chloride groups. In considering, the time spent in closed arms by offspring, pups spent significantly much time than control group, while, time spent in open arms of elevated plus maze decreased significantly in all treated groups than control group. On the other hand, number of entries in open arms significantly decreased in treated groups than control one.
\end{abstract}

Keywords: Aluminum Toxicity, Rats, Learning Ability, Behavior

\section{Introduction}

Livestock subjected to wide variety of stressors (e.g. thermal, nutritional, environmental and productive) but there have been a significant increase in interest in psychological or behavioral stressors due to concern over animal wellbeing. The existence of behavioral needs or instinctive derives (e.g. for exercise, social interaction or control over environmental stimuli) have become important issues [12]. [7] observed significant alterations in feed and water consumption during gestation in dams exposed to aluminum, also [19] demonstrated that melatonin reduced oxidative damage induced by aluminum in rat kidney and differences in feed and water intake of aluminum treated rats from controls. A single oral dose of aluminum nitrate monohydrate $1327 \mathrm{mg} / \mathrm{kg}$ given to mice on gestation day 12 and found that aluminum induced maternal toxicity by reduction in feed consumption [9]. Furthermore, [16] when assed the influence of long term aluminum chloride intake on biochemical parameters by administration of aluminum chloride in drinking water at a dose of $80 \mathrm{mg} / \mathrm{l}$ for thr.ee months found that feed and water intake decreased. [1] stated that exposure to aluminum was associated with significant reductions in spontaneous locomotor behavior in open field test and not caused any significant alterations of the animal's performance in Rota-rod test, while there were significant reductions in exploratory activity in open field test.

[26] reported that four out of six rats consumed aluminum from 16 months of age to the conclusion of their lifespan (average 29.8 months) in an amount ( $1.5 \mathrm{mg} / \mathrm{kg}$ body weight) continued to perform the memory task in old age without significant deficit and the remaining two obtained significantly lower mean memory scores in old age than in middle age. Also, there are considerable interest generated in prenatal influence of environmental and nutritional factors on physical and mental development of offspring where, prenatal exposure of rat pups to aluminum and lead produced neurobehavioral impairments and learning deficits characterized by learning disabilities, hypoactivites and high emotionality. In addition, experimental designs and models of laboratory animals are one of great chance to stimulate human maternal environment and exploring the potential risk of such agents [15].

The objectives of this study are to investigate the effect of 
anhydrous aluminum chloride toxicity on welfare of rats by measuring behavior of adult female rats and learning ability of their offspring.

\section{Materials and Methods}

\subsection{Animals}

This investigation was carried out at Animal Husbandry and animal Wealth Development Department, Faculty of Veterinary Medicine, Alexandria University, 2012.

A total of 35 Sprague-Dawley pregnant female rats (3 months \& 110-130g) were allotted into four groups, group one received $2 \mathrm{~g} / \mathrm{l}$ anhydrous aluminum chloride in drinking water $(n=10)$ [13], group two received $3 g / 1$ anhydrous aluminum chloride in drinking water $(n=10)$ [25]., group thr.ee received $3.5 \mathrm{~g} / \mathrm{l}$ anhydrous aluminum chloride in drinking water $(n=10)$ [20] and group four received water without anhydrous aluminum chloride $(\mathrm{n}=5)$ daily from day 8 pregnancy till weaning [8].

\subsection{Management}

Rats were fed ration containing $16.3 \%$ crude protein, $6.8 \%$ fat and $3.5 \%$ crude fiber, housed in 35 individual breeding plastic cages $(37 \times 30 \times 14 \mathrm{~cm})$ with $1-2 \mathrm{~cm}$ wood shaving bedding replaced two times per week. Rats were kept under natural light-dark cycle without any alteration in lighting program.

Vaginal smears were done to detect the time of positive estrus according to [14] then mating took place by monogamous system where one female was regularly mated by one male introduced to females in breeding cages [10] and then persists with pups till weaning. Pregnancy was detected by vaginal smears on the next morning and the day of finding sperms was called day zero of gestation [18].

\subsection{Behavioral Observations}

Rats were observed thr.ee times weekly and four hours daily within periods of late morning and early afternoon. Focal sample observation was carried out according to [21].

The observed patterns were ingestive, body care, resting, movement, investigatory behavior, while, maternal behavior carried out according to [11] including licking (grooming), nursing, nest building and retrieving.

Learning ability was measured by using the elevated plus maze according to [22], where the elevated plus -maze apparatus was made of smooth brown opaque platforms with two open arms $(50 \times 10 \mathrm{~cm})$ and two closed arms of the same size, the wall of this chamber was $40 \mathrm{~cm}$ high and the whole apparatus was elevated $50 \mathrm{~cm}$ above floor. Each rat was placed in the central square $(10 \times 10 \mathrm{~cm})$ facing closed arm. At the end of each trial lasting $5 \mathrm{~min}$, the arms was cleaned and dried to remove excreta. The recorded parameters were time spent in open or closed arms, time of latency in seconds that rats took to enter open or closed arm, number of entries into open and closed arms and ratio spent in open and/or closed arms expressed as percentage.

\subsection{Statistical Analysis}

The behavioral data was analyzed by two way analysis of variance and learning ability data was analyzed by one way analysis of variance proc GLM by SAS software version 6 , $4^{\text {th }}$ Edition, SAS Institute, Cary, NC. USA.

\section{Results and Discussion}

The data presented in Table (1) showed that feeding time increased significantly $(\mathrm{p}<0.05)$ in rats treated with $2 \mathrm{~g} / 1$ $(9.62+0.66 \mathrm{~min} / \mathrm{hr}$.) and $3.5 \mathrm{~g} / \mathrm{l}$ anhydrous aluminum chloride $(7.87 \pm 0.61 \mathrm{~min} / \mathrm{hr}$.) than control group $(5.65 \pm 0.59$ $\mathrm{min} / \mathrm{hr}$.), while, standing time decreased significantly $(\mathrm{P}<0.05)$ in rats treated with $3 \mathrm{~g} / 1$ anhydrous aluminum chloride $(0.20 \pm 0.05 \mathrm{~min} / \mathrm{hr} .$.$) than control group (0.62 \pm 0.18$ $\mathrm{min} / \mathrm{hr}$.), moreover, lying time decreased significantly $(\mathrm{P}<0.05)$ in rats treated with $2 \mathrm{~g} / 1$ anhydrous aluminum chloride $(28.89 \pm 1.83 \mathrm{~min} / \mathrm{hr}$.) than other groups.

Table 1. least square means and their standard error of the effect of aluminum chloride (Alcl ${ }_{3}$ ) and period of pregnancy and lactation on ingestive and resting behavior of rats.

\begin{tabular}{|c|c|c|c|c|}
\hline \multirow[b]{2}{*}{ Item } & \multicolumn{2}{|c|}{ Ingestive behavior } & \multicolumn{2}{|c|}{ Resting behavior } \\
\hline & $\begin{array}{l}\text { Feeding } \\
\text { (Min/hr.) }\end{array}$ & $\begin{array}{c}\text { Drinking } \\
\text { (Time/hr.) }\end{array}$ & $\begin{array}{l}\text { Standing } \\
(\mathrm{Min} / \mathrm{hr} .)\end{array}$ & $\begin{array}{l}\text { Lying } \\
\text { (Min/hr.) }\end{array}$ \\
\hline \multicolumn{5}{|l|}{ Treatment } \\
\hline Control & $5.65 \pm 0.59^{c}$ & $0.66 \pm 0.08^{\mathrm{a}}$ & $0.62 \pm 0.18^{\mathrm{a}}$ & $36.78 \pm 2.05^{\mathrm{a}}$ \\
\hline $2 \mathrm{~g} / 1 \mathrm{Alcl}_{3}$ & $9.62 \pm 0.66^{\mathrm{a}}$ & $0.73+0.06^{\mathrm{a}}$ & $0.39 \pm 0.09^{\mathrm{ab}}$ & $28.89 \pm 1.83^{b}$ \\
\hline $3 \mathrm{~g} / 1 \mathrm{Alcl}_{3}$ & $6.16+0.39^{c}$ & $0.54+0.07^{\mathrm{a}}$ & $0.20 \pm 0.05^{\mathrm{b}}$ & $36.91 \pm 1.61^{\mathrm{a}}$ \\
\hline $3.5 \mathrm{~g} / 1 \mathrm{Alcl}_{3}$ & $7.87 \pm 0.61^{\mathrm{b}}$ & $0.69 \pm 0.07^{\mathrm{a}}$ & $0.43 \pm 0.08^{\mathrm{ab}}$ & $36.93 \pm 1.42^{\mathrm{a}}$ \\
\hline \multicolumn{5}{|l|}{ Period } \\
\hline $2^{\text {nd }}$ Week pregnancy & $4.57 \pm 0.56^{\mathrm{c}}$ & $0.45 \pm 0.07^{\mathrm{c}}$ & $0.74 \pm 0.15^{\mathrm{a}}$ & $54.98 \pm 0.65^{\mathrm{a}}$ \\
\hline $3^{\text {rd }}$ Week pregnancy & $4.70 \pm 0.51^{\mathrm{c}}$ & $0.52 \pm 0.07^{\mathrm{bc}}$ & $0.40 \pm 0.10^{\mathrm{b}}$ & $55.51 \pm 0.58^{\mathrm{a}}$ \\
\hline $1^{\text {st }}$ Week lactation & $5.93 \pm 0.49^{c}$ & $0.68 \pm 0.07^{b}$ & $0.36 \pm 0.08^{\mathrm{b}}$ & $22.82 \pm 1.44^{\mathrm{b}}$ \\
\hline $2^{\text {nd }}$ Week lactation & $8.48 \pm 0.65^{\mathrm{b}}$ & $0.68 \pm 0.07^{b}$ & $0.25 \pm 0.07^{\mathrm{b}}$ & $19.92 \pm 1.16^{\mathrm{c}}$ \\
\hline $3^{\text {rd }}$ Week lactation & $11.27 \pm 0.90^{\mathrm{a}}$ & $0.94+0.10^{\mathrm{a}}$ & $0.15+0.07^{\mathrm{b}}$ & $19.81+1.09^{\mathrm{c}}$ \\
\hline
\end{tabular}

Means within the same column under the same category carry different superscripts are significantly different.

During last two weeks of pregnancy and during lactation period feeding time and drinking frequency increased sig- nificantly $(11.27 \pm 0.90 \mathrm{~min} / \mathrm{hr}$. and $0.94 \pm 0.10 \mathrm{time} / \mathrm{hr}$. $\mathrm{p}<0.05$ ) while, standing time decreased gradually during 
experimental period especially during last week of lactation, while rats exhibited much lying time during last two weeks of pregnancy than during lactation period with a gradual decrease during lactation period. These results are in close accordance with [7] who found no significant alterations in feed consumption or water consumption during gestation in dams exposed to aluminum and [19] who demonstrated that melatonin reduces oxidative damage induced by aluminum in rat kidney and found that feed and water intake of aluminum treated rats were not different from controls. While, [9] found that single oral dose of aluminum nitrate monohydrate $1327 \mathrm{mg} / \mathrm{kg}$ given to mice on gestation day 12 induced maternal toxicity by reduction in feed consumption. Furthermore, [16] when assed the influence of long term aluminum chloride intake on biochemical parameters by administration of aluminum chloride in drinking water at a dose of $80 \mathrm{mg} / \mathrm{l}$ for thr.ee months found that feed and water intake decreased.

Licking and scratching frequencies (Table 2) decreased significantly $(\mathrm{P}<0.05)$ in rats treated with $3 \mathrm{~g} / 1$ and $3.5 \mathrm{~g} / 1$ anhydrous aluminum chloride than control group $(2.10+0.19$ and $1.98 \pm 0.19$ vs. $3.12 \pm 0.51 \mathrm{Time} / \mathrm{hr}$.), while treatment had no significant effect on movement activities and investigation of cage and trough frequencies. However, there were
Moreover, findings concerning effect of gradual increase in the movement activities and trough exploration throughout pregnancy and lactation period with highest increment during last week of lactation $(1.98 \pm 0.20$ and $0.09 \pm 0.02$ Time/hr.), while, dams exhibited significantly $(\mathrm{P}<0.05)$ and gradual decline in licking frequency and cage investigation from $2^{\text {nd }}$ week of pregnancy $(3.60 \pm 0.40$ and $1.81 \pm 0.23$ Time/hr.) till $3^{\text {rd }}$ week of lactation in licking $(1.58 \pm 0.22$ Time/hr.) and $2^{\text {nd }}$ week of lactation for cage exploration $(0.99 \pm 0.14 \mathrm{Time} / \mathrm{hr}$.). The influence of treatment on movement activities agreed with [6] who reported that exposure of rats to aluminum nitrate monohydrate had no significant effect on locomotor activity in an open field test. Furthermore, [7] found no alterations in the motor activity in the open field test for aluminum treated rats. Also, [23] reported that exposing rats to aluminum in drinking water did not alter significantly motor activity in the open field test. while, [1] stated that exposure to aluminum was associated with significant reductions in spontaneous locomotor behavior in open field test and not caused any significant alterations of the animal's performance in Rota-rod test, while there were significant reductions in exploratory activity in open field test.

Table 2. least square means and their standard error of the effect of aluminum chloride (Alcl 3 ) and period of pregnancy and lactation on movement activities, body care and investigatory behavior of rats.

\begin{tabular}{|c|c|c|c|c|c|}
\hline \multirow[b]{2}{*}{ Item } & \multicolumn{2}{|c|}{ Body care behavior } & \multicolumn{2}{|c|}{ Investigatory behavior } & \multirow[b]{2}{*}{$\begin{array}{l}\text {-Movement } \\
\text { (Time/hr.) }\end{array}$} \\
\hline & $\begin{array}{l}\text { Licking } \\
\text { (Time/hr.) }\end{array}$ & $\begin{array}{l}\text { Scratching } \\
\text { (Time/hr.) }\end{array}$ & $\begin{array}{l}\text { Cage } \\
\text { (Time/hr.) }\end{array}$ & Trough (Time/hr.) & \\
\hline \multicolumn{6}{|l|}{ Treatment } \\
\hline Control & $3.12 \pm 0.51^{\mathrm{a}}$ & $3.08 \pm 0.54^{\mathrm{a}}$ & $1.51 \pm 0.27^{\mathrm{a}}$ & $0.07 \pm 0.02^{\mathrm{a}}$ & $1.53 \pm 0.18^{\mathrm{a}}$ \\
\hline $2 \mathrm{~g} / 1 \mathrm{Alcl}_{3}$ & $3.01 \pm 0.22^{\mathrm{a}}$ & $3.48 \pm 0.25^{\mathrm{a}}$ & $1.49 \pm 0.16^{\mathrm{a}}$ & $0.06 \pm 0.01^{\mathrm{a}}$ & $1.35 \pm 0.08^{\mathrm{a}}$ \\
\hline $3 \mathrm{~g} / 1 \mathrm{Alcl}_{3}$ & $2.10 \pm 0.19^{b}$ & $2.37 \pm 0.20^{\mathrm{b}}$ & $1.19 \pm 0.13^{\mathrm{a}}$ & $0.11 \pm 0.02^{\mathrm{a}}$ & $1.58 \pm 0.13^{\mathrm{a}}$ \\
\hline $3.5 \mathrm{~g} / 1 \mathrm{Alcl}_{3}$ & $1.98+0.19^{\mathrm{b}}$ & $2.11 \pm 0.14^{\mathrm{b}}$ & $1.45 \pm 0.14^{\mathrm{a}}$ & $0.07 \pm 0.01^{\mathrm{a}}$ & $1.82 \pm 0.21^{\mathrm{a}}$ \\
\hline \multicolumn{6}{|l|}{ Period } \\
\hline $2^{\text {nd }}$ Week pregnancy & $3.60 \pm 0.40^{\mathrm{a}}$ & $4.20 \pm 0.45^{\mathrm{a}}$ & $1.81 \pm 0.23^{\mathrm{a}}$ & $0.10 \pm 0.02^{\mathrm{a}}$ & $1.15 \pm 0.14^{\mathrm{c}}$ \\
\hline $3^{\text {rd }}$ Week pregnancy & $2.62 \pm 0.26^{\mathrm{b}}$ & $2.45 \pm 0.24^{\mathrm{c}}$ & $1.37 \pm 0.17^{\mathrm{ab}}$ & $0.07 \pm 0.02^{\mathrm{a}}$ & $1.29 \pm 0.14^{\mathrm{bc}}$ \\
\hline $1^{\text {st }}$ Week lactation & $2.80 \pm 0.21^{\mathrm{b}}$ & $3.17 \pm 0.24^{\mathrm{b}}$ & $1.38 \pm 0.18^{\mathrm{ab}}$ & $0.08 \pm 0.02^{\mathrm{a}}$ & $1.76 \pm 0.14^{\mathrm{ab}}$ \\
\hline $2^{\text {nd }}$ Week lactation & $1.75 \pm 0.19^{c}$ & $2.04 \pm 0.16^{\mathrm{c}}$ & $0.99 \pm 0.14^{\mathrm{b}}$ & $0.05 \pm 0.01^{\mathrm{a}}$ & $1.71 \pm 0.22^{\mathrm{ab}}$ \\
\hline $3^{\text {rd }}$ Week lactation & $1.58 \pm 0.22^{\mathrm{c}}$ & $1.71 \pm 0.18^{\mathrm{c}}$ & $1.42 \pm 0.18^{\mathrm{ab}}$ & $0.09 \pm 0.02^{\mathrm{a}}$ & $1.98 \pm 0.20^{\mathrm{a}}$ \\
\hline
\end{tabular}

Means within the same column under the same category carry different superscripts are significantly different.

Among the four types of treatments the maternal behavior of rats including licking frequency of pups and nursing time were significantly higher $(\mathrm{P}<0.05)$ in dams treated with $2 \mathrm{~g} / \mathrm{l}$ anhydrous aluminum chloride $(3.48 \pm 0.37$ time $/ \mathrm{hr}$. and $37.49 \pm 1.40 \mathrm{~min} / \mathrm{hr}$., than other groups and non-significantly higher in nest building and retrieving frequencies $(0.75 \pm 0.15$ and $0.27 \pm 0.07 \mathrm{Time} / \mathrm{hr}$. , respectively). Alterations in behavior of mother are known to affect infant development and several drugs have been shown to disrupt elements of maternal behavior thus any disturbance to maternal care or the delicate mother-pup relationship may explain differential patterns of behavior in the offspring rather than direct effects of prenatal exposure to a toxicant and the result of a pilot study suggested that differences exist in the pattern of maternal behavior displayed by control and aluminum exposed mothers as control mothers spent more time involved in the pup-directed behaviors of nursing and licking and less time in nest building during the first two postnatal weeks than dams treated with aluminum during gestation while treated mothers had a longer latency to retrieve on postnatal day 3 although this difference did not reach significance [17].

During lactation period, dams exhibited significantly $(\mathrm{P}<0.05)$ gradually decline in licking frequency of pups and nursing time from $1^{\text {st }}$ week $(3.49 \pm 0.33$ time $/ \mathrm{hr}$. and $37.15 \pm 1.33 \mathrm{~min} / \mathrm{hr}$. $)$ till $3^{\text {rd }}$ week $(1.40+0.18 \mathrm{time} / \mathrm{hr}$. and $32.97 \pm 0.98 \mathrm{~min} / \mathrm{hr}$.). However, nest building and retrieving frequencies were higher during $2^{\text {nd }}$ week lactation 
$(0.83 \pm 0.16$ and $0.32 \pm 0.06 \mathrm{Time} / \mathrm{hr}$.) and lower during last week of lactation $(0.33 \pm 0.07$ and $0.02 \mathrm{Time} / \mathrm{hr}$.). The rapid onset of maternal behavior in newly parturient rat is stimulated in parturition by the hormonal changes accompanying pregnancy, the parturient female displays full complement of maternal behavior at birth and in some cases before par- turition then decline with growth of pups [5]. [2] reported that aluminum treated mothers had no significant effect on nest building, retrieval of pups to nest and time spent with young following exposure to $\mathrm{ALCL}_{3}$ in the dam's diet from day 8 of gestation till parturition.

Table 3. least square means and their standard error of the effect of aluminum chloride (Alcl $)_{3}$ and period of lactation on maternal behavior of rats.

\begin{tabular}{|c|c|c|c|c|}
\hline Item & $\begin{array}{l}\text { Licking } \\
\text { (Time/hr.) }\end{array}$ & $\begin{array}{l}\text { Nursing } \\
\text { (Min/hr.) }\end{array}$ & $\begin{array}{l}\text { Nest building } \\
\text { (Time/hr.) }\end{array}$ & $\begin{array}{l}\text { Retrieving } \\
\text { (Time/hr.) }\end{array}$ \\
\hline \multicolumn{5}{|l|}{ Treatment } \\
\hline Control & $2.30 \pm 0.34^{\mathrm{b}}$ & $33.38 \pm 4.98^{b}$ & $0.39 \pm 0.06^{\mathrm{a}}$ & $0.10 \pm 0.01^{\mathrm{a}}$ \\
\hline $2 \mathrm{~g} / 1 \mathrm{Alcl}_{3}$ & $3.48 \pm 0.37^{\mathrm{a}}$ & $37.49 \pm 1.40^{\mathrm{a}}$ & $0.75 \pm 0.15^{\mathrm{a}}$ & $0.27 \pm 0.07^{\mathrm{a}}$ \\
\hline $3 \mathrm{~g} / 1 \mathrm{Alcl}_{3}$ & $2.08 \pm 0.21^{\mathrm{b}}$ & $34.81 \pm 1.10^{\mathrm{ab}}$ & $0.64 \pm 0.17^{\mathrm{a}}$ & $0.19 \pm 0.04^{\mathrm{a}}$ \\
\hline $3.5 \mathrm{~g} / 1 \mathrm{Alcl}_{3}$ & $1.63 \pm 0.17^{\mathrm{b}}$ & $32.72 \pm 1.31^{\mathrm{b}}$ & $0.51 \pm 0.09^{\mathrm{a}}$ & $0.19 \pm 0.04^{\mathrm{a}}$ \\
\hline \multicolumn{5}{|l|}{ Period } \\
\hline $1^{\text {st }}$ Week lactation & $3.49 \pm 0.33^{\mathrm{a}}$ & $37.15+1.33^{\mathrm{a}}$ & $0.64+0.13^{\mathrm{ab}}$ & $0.23 \pm 0.06^{\mathrm{a}}$ \\
\hline $2^{\text {nd }}$ Week lactation & $2.26+0.17^{b}$ & $34.19 \pm 1.14^{\mathrm{ab}}$ & $0.83 \pm 0.16^{\mathrm{a}}$ & $0.32+0.06^{\mathrm{a}}$ \\
\hline $3^{\text {rd }}$ Week lactation & $1.40 \pm 0.18^{\mathrm{c}}$ & $32.97 \pm 0.98^{\mathrm{b}}$ & $0.33 \pm 0.07^{\mathrm{b}}$ & $0.05 \pm 0.02^{\mathrm{b}}$ \\
\hline
\end{tabular}

Means within the same column under the same category carry different superscripts are significantly different.

Pups which parentally exposed to aluminum had a greater effect on all neurobehavioral parameters and suffered from learning deficits in which the time needed for correct choice in maze leaning test was significantly higher as compared to control ones [15]. Moreover, the amount aluminum chloride ingested by rats had significantly longer $(\mathrm{P}<0.05)$ time spent in latency to closed arms and time spent in closed arm for $3 \mathrm{~g} / \mathrm{l}$ group $(6.80 \pm 1.32$ and $255.41 \pm 8.25 \mathrm{sec})$ and shorter time in offspring of rats treated with $2 \mathrm{~g} / \mathrm{l}$ aluminum chloride $(4.59 \pm 0.96$ and $254.43+7.51 \mathrm{sec})$ and very short time in pups from dam fed no aluminum (1.79 \pm 0.93 and $170.75 \pm 22.23$ $\mathrm{sec})$. However, the number of entries to closed arms was significantly higher in offspring from dam ingested $3.5 \mathrm{~g} / 1$ aluminum $(3.48 \pm 0.28)$ than those ingested $3 \mathrm{~g} / 1$ aluminum $(2.75 \pm 0.28)$ and $2 \mathrm{~g} / \mathrm{l}$ aluminum $(2.54 \pm 0.22)$.

The presented data in Table (4) deducted that pups from dams that did not receive any aluminum spent very short time to enter open arms in elevated plus maze $(1.07 \pm 0.49 \mathrm{sec})$ and spent very long time in open arms $(127.39 \pm 22.48 \mathrm{sec})$ with much number of entries into open arms $(2.07 \pm 0.26)$ and highly open/closed arm ratio $(99.38+0.50)$. On contrary dams consumed $2 \mathrm{~g} / \mathrm{l}$ aluminum chloride spent significantly $(\mathrm{P}<0.05)$ longer time to enter open arms $(1.69 \pm 0.55 \mathrm{sec})$, spent short time in it $(36.56 \pm 7.65 \mathrm{sec})$ and less number of entries $(1.31 \pm 0.21)$ and low level of open/closed ration $(97.32 \pm 0.9)$. This could be attributed to several $\mathrm{Mg}^{+2} \mathrm{de}-$ pendent enzyme systems which could be disturbed as a result of its substitution with aluminum; moreover, infants might be at particular risk of aluminum toxicity because of the immaturity of the blood-brain barrier, the gut and renal system. Furthermore, the hippocampus and the cerebral cortex are the key structures of memory formation because the hippocampus is especially indispensable in the integration of spatial formation, a decline in learning ability may be induced by the deterioration of hippocampal function and however the frontal cortex plays a critical role in both spatial and no spatial working memory. In addition, there may be domain-specific subdivisions within dorsal and ventral regions of the lateral prefrontal cortex which sub serve working memory for spatial and no spatial information [3].

Table 4. least square means and their standard error of the effect of aluminum chloride ( Alcl $_{3}$ ) on learning ability of rat's offspring.

\begin{tabular}{|c|c|c|c|c|c|c|c|}
\hline Item & $\begin{array}{l}\text { Latency to } \\
\text { closed arm } \\
\text { (Sec) }\end{array}$ & $\begin{array}{l}\text { Time spent in } \\
\text { closed arm (Sec) }\end{array}$ & $\begin{array}{l}\text { No of entries in } \\
\text { closed arm }\end{array}$ & $\begin{array}{l}\text { Latency to open } \\
\operatorname{arm}(\mathrm{Sec})\end{array}$ & $\begin{array}{l}\text { Time spent in } \\
\text { open arm (Sec) }\end{array}$ & $\begin{array}{l}\text { No of entries in } \\
\text { open arm }\end{array}$ & $\begin{array}{l}\text { Ratio of } \\
\text { open/closed arms }\end{array}$ \\
\hline \multicolumn{8}{|l|}{ Treatment } \\
\hline Control & $1.79 \pm 0.93^{\mathrm{b}}$ & $170.75 \pm 22.23^{\mathrm{b}}$ & $3.36 \pm 0.49^{\mathrm{ab}}$ & $1.07 \pm 0.49^{\mathrm{a}}$ & $127.39 \pm 22.48^{\mathrm{a}}$ & $2.07 \pm 0.26^{\mathrm{a}}$ & $99.38 \pm 0.50^{\mathrm{a}}$ \\
\hline $2 \mathrm{~g} / 1 \mathrm{Alcl}_{3}$ & $4.59 \pm 0.96^{\mathrm{ab}}$ & $254.43 \pm 7.51^{\mathrm{a}}$ & $2.54 \pm 0.22^{\mathrm{b}}$ & $3.28 \pm 0.90^{\mathrm{a}}$ & $38.20 \pm 6.68^{\mathrm{b}}$ & $1.41 \pm 0.21^{\mathrm{b}}$ & $97.54 \pm 0.52^{\mathrm{b}}$ \\
\hline $3 \mathrm{~g} / 1 \mathrm{Alcl}_{3}$ & $6.80 \pm 1.32^{\mathrm{a}}$ & $255.41 \pm 8.25^{\mathrm{a}}$ & $2.75 \pm 0.28^{\mathrm{ab}}$ & $1.69 \pm 0.55^{\mathrm{a}}$ & $36.56 \pm 7.65^{b}$ & $1.31 \pm 0.21^{\mathrm{b}}$ & $97.32 \pm 0.49^{\mathrm{b}}$ \\
\hline $3.5 \mathrm{~g} / 1 \mathrm{Alcl}_{3}$ & $6.75 \pm 1.34^{\mathrm{a}}$ & $248.48 \pm 7.93^{\mathrm{a}}$ & $3.48 \pm 0.28^{\mathrm{a}}$ & $1.92 \pm 0.71^{\mathrm{a}}$ & $42.85 \pm 7.97^{\mathrm{b}}$ & $1.40 \pm 0.16^{\mathrm{b}}$ & $97.11 \pm 0.53^{b}$ \\
\hline
\end{tabular}

Means within the same column under the same category carry different superscripts are significantly different.

Moreover, vital processes involving rapid $\mathrm{Ca}+2$ exchanges between extracellular and intracellular calcium compartments would be impaired by substitution of $\mathrm{Al}+3$ [4]. In this regard, the impairment of neural exchange of $\mathrm{Ca}+2$ ions by aluminum would result in vitiation and spoiling of dopaminergic pathways (DA) since the accumulation of dopaminergic pathways (DA) is mainly mediated through its effects on potassium and calcium channels [27].

From these results it could be concluded that administration of aluminum chloride to rats in drinking water resulted 
in deviations in the normal behavior of adult female rats and this deviation extend to the offspring of the dam drink water containing aluminum chloride which was obvious in the form of increment in the time spent in closed arms of elevated plus maze and avoidance of open arms of the maze.

\section{References}

[1] Abdel-Aal, R.A.; Assi, A.A. and Kostandy, B.B. Rivastigmine reverses aluminum induced behavioral changes in rats. European Journal Behavioral Pharmacology. 659:169-176 (2011).

[2] Bernuzzi, V.; Desor, D. and Lehr., P.R. Effects of prenatal aluminum exposure on neuromotor maturation in the rat. Neurobehav. Toxicol. Teratol. 8:115-119 (1986).

[3] Bimonte-Nelson, H.A.; Hunter, C.L.; Nelson, M.E. and Granholm, A.C. Frontal cortex BDNF levels correlate with working memory in an animal model of Down syndrome. Behav.Brain.Res.139:47-57 (2003).

[4] Bonnie, L. and Carson, S. Aluminum compound. A review of toxicological literature. Abridged final report, Scott, M (2000).

[5] Bridges, R.S. and Ronsheim, P.M. Prolactin regulation of maternal behavior in rats: Bromocriptine treatment delays and prolactin promotes the rapid onset of behavior. Endocrinology. 126:837-848 (1990).

[6] Colomina, M.T.; Roig, J.L.; Sanchez, D.J. and Domingo, J.L. Influence of age on aluminum induced neurobehavioral effects and morphological changes in rat brain. Neurotoxicology. 23:775-781 (2002).

[7] Colomina, M.T.; Rogi. J.L; Torrente, M.; Vicens, P.and Domingo, J.L. Concurrent exposure to aluminum and stress during pregnancy in rats: Effects on postnatal development and behavior of the offspring. Neurotoxicol.Teratol.27: 565-574 (2005).

[8] Delville, Y. Exposure to lead during development alters aggressive behavior in golden hamsters. Neurotoxicol. Teratol. 21:445-449 (1999).

[9] Domingo, J.L.; Gomez, M. and Colomina, M.T. Risks of aluminum exposure during pregnancy. Contributions to Science. 1: 479-487 (2000).

[10] Fatma, H.S. Influence of some environmental stressors on response and behavior of laboratory rats. MVSC, Thesis, Cairo university, beni-suef branch, faculty of veterinary medicine (2005).

[11] Ferreira, A.; Pereira, M.; Agrati, D.; Uriarte, N. and Fermandez-Guasti, A. Role of maternal behavior on aggression, fear and anxiety. Physiology and Behavior. 77:197-204 (2002).

[12] Friend, T.H. Symposium: Response of animals to stress. J. Dairy. Sci. 74:292-303 (1991).

[13] Gromysz-Kalkowska, K.; Kanoniuk, D.; Szubartowska, E. and Unkiewicz-Winiarczyk, A. Influence of drinking water-administered aluminum on morphology and respiratory function of blood in rats. Polish Journal of Environmental Studies. 13: 515-519 (2004).
[14] Harkness, J.E. and Wagner, J.E. Biology and Husbandry. In: the biology and medicine of rabbits and rodents. $\left(2^{\text {nd }} \mathrm{ed}\right)$, Lea and Feiger: 36-51 (1983).

[15] Kaoud, H.A.; Kamel. M.M. and Abd ELRazek. A.H. Effect of neurotoxic metals on neurobehavioral and learning ability in rat pups. J. Egypt. Vet. Med. Assoc. 68: 1-14 (2008).

[16] Kowalczyk, E.; Kopff, A.; Kedziora, J.; Blaszczyk, J.; Kopff, M.; Niedworok, J. and Fijalkowski, P. Effect of long-term aluminum chloride intoxication on selected biochemical parameters and oxidative -antioxidative balance in experimental animals. Polish Journal of Environmental Studies. 13:41-43 (2004).

[17] Laviola, G.; Sedowofia, k.; Innes, J.; Clayton, R. and Manning, A. Genetic differences in maternal behavior patterns in mice administered phenobarbital during pregnancy. Psychopharmacology. 102: 383-390 (1990).

[18] Luna, L.G. Berg's method for spermatozoa. In: Manual od histological staining methods of the armed forces institute of pathology, $3^{\text {rd }}$ edition, 117-118, McGraw-Hill, New york (1968).

[19] Mahieu, S.; Contini, M.D.C.; Gonzalez, M. and Miller, N.C. Melatonin reduces oxidative damage induced by aluminum in rat kidney. Toxicology Letters. 190:9-15 (2009).

[20] Misawa, T. and Shigeta, S. Behavioral effects of repeated aluminum administration in the rat. Takai.Jo.Exp.Din. Med. 17: 155-159 (1992).

[21] Morimoto, A.; Nakamon, T.; Morimot, k.; Tan, V. and Murakami, N. The central role of corticotrophin-releasing factor (CRF-41) in psychological stress in rats. Journal of Physiology.460:221-229 (1993).

[22] Pellow, S.; Chopin, P.; File, S.E. and Briley, M. Validation of open-closed arm entries in an elevated plus-maze as a measure of anxiety in the rat. J. Neurosci. Methods. 14:149-167 (1985).

[23] Roig, J.L.; Fuentes, S.; Teresa, C.M.; Colomina, M.; Vicens, P. and Domingo, J.L. Aluminum, restraint stress and aging: Behavioral effects in rats after 1 and 2 years of aluminum exposure. Toxicology. 218:112-124 (2006).

[24] Schetinger, M.R.C.; Bonan, C.D.; Morsch, V.M.; Boher, D.; Valentin, L.M. and Rodrigues, S.R. Effects of aluminum sulphate on delta-aminolevulinate dehydratase from kidney, brain and liver of adult mice. Braz.J.Med.Biol.Res.32:761-766 (1999).

[25] Walton, J.R. A longitudinal study of rats chr.onically exposed to aluminum at human dietary levels. Neurosci. Lett. 412:29-33 (2007).

[26] Waxman, S.G. Correlative neui-oanatomy 23, $3^{\text {rd }}$ ed, Appetton and lang, California (1997).

[27] Bernuzzi, V.; Desor, D. and Lehr., P.R. Effects of prenatal aluminum exposure on neuromotor maturation in the rat. Neurobehav. Toxicol. Teratol. 8:115-119 (1986).

[28] Bimonte-Nelson, H.A.; Hunter, C.L.; Nelson, M.E. and Granholm, A.C. Frontal cortex BDNF levels correlate with working memory in an animal model of Down syndrome. Behav.Brain.Res.139:47-57 (2003).

[29] Bonnie, L. and Carson, S. Aluminum compound. A review of 
toxicological literature. Abridged final report, Scott, M (2000).

[30] Bridges, R.S. and Ronsheim, P.M. Prolactin regulation of maternal behavior in rats: Bromocriptine treatment delays and prolactin promotes the rapid onset of behavior. Endocrinology. 126:837-848 (1990).

[31] Colomina, M.T.; Roig, J.L.; Sanchez, D.J. and Domingo, J.L. Influence of age on aluminum induced neurobehavioral effects and morphological changes in rat brain. Neurotoxicology. 23:775-781 (2002).

[32] Colomina, M.T.; Rogi. J.L; Torrente, M.; Vicens, P.and Domingo, J.L. Concurrent exposure to aluminum and stress during pregnancy in rats: Effects on postnatal development and behavior of the offspring. Neurotoxicol.Teratol.27: 565-574 (2005).

[33] Delville, Y. Exposure to lead during development alters aggressive behavior in golden hamsters. Neurotoxicol. Teratol. 21:445-449 (1999).

[34] Domingo, J.L.; Gomez, M. and Colomina, M.T. Risks of aluminum exposure during pregnancy. Contributions to Science. 1: 479-487 (2000).

[35] Fatma, H.S. Influence of some environmental stressors on response and behavior of laboratory rats. MVSC, Thesis, Cairo university, beni-suef branch, faculty of veterinary medicine (2005)

[36] Ferreira, A.; Pereira, M.; Agrati, D.; Uriarte, N. and Fermandez-Guasti, A. Role of maternal behavior on aggression, fear and anxiety. Physiology and Behavior. 77:197-204 (2002).

[37] Friend, T.H. Symposium: Response of animals to stress. J. Dairy. Sci. 74:292-303 (1991).

[38] Gromysz-Kalkowska, K.; Kanoniuk, D.; Szubartowska, E. and Unkiewicz-Winiarczyk, A. Influence of drinking water-administered aluminum on morphology and respiratory function of blood in rats. Polish Journal of Environmental Studies. 13: 515-519 (2004).

[39] Harkness, J.E. and Wagner, J.E. Biology and Husbandry. In: the biology and medicine of rabbits and rodents. (2nd ed), Lea and Feiger: 36-51 (1983).

[40] Kaoud, H.A.; Kamel. M.M. and Abd ELRazek. A.H. Effect of neurotoxic metals on neurobehavioral and learning ability in rat pups. J. Egypt. Vet. Med. Assoc. 68: 1-14 (2008).

[41] Kowalczyk, E.; Kopff, A.; Kedziora, J.; Blaszczyk, J.; Kopff, M.; Niedworok, J. and Fijalkowski, P. Effect of long-term aluminum chloride intoxication on selected biochemical parameters and oxidative -antioxidative balance in experimental animals. Polish Journal of Environmental Studies. $13: 41-43$ (2004).

[42] Laviola, G.; Sedowofia, k.; Innes, J.; Clayton, R. and Manning, A. Genetic differences in maternal behavior patterns in mice administered phenobarbital during pregnancy. Psychopharmacology. 102: 383-390 (1990).

[43] Luna, L.G. Berg`s method for spermatozoa. In: Manual od histological staining methods of the armed forces institute of pathology, 3rd edition, 117-118, McGraw-Hill, New york (1968).

[44] Mahieu, S.; Contini, M.D.C.; Gonzalez, M. and Miller, N.C. Melatonin reduces oxidative damage induced by aluminum in rat kidney. Toxicology Letters. 190:9-15 (2009).

[45] Misawa, T. and Shigeta, S. Behavioral effects of repeated aluminum administration in the rat. Takai.Jo.Exp.Din. Med. 17: 155-159 (1992).

[46] Morimoto, A.; Nakamon, T.; Morimot, k.; Tan, V. and Murakami, N. The central role of corticotrophin-releasing factor (CRF-41) in psychological stress in rats. Journal of Physiology.460:221-229 (1993).

[47] Pellow, S.; Chopin, P.; File, S.E. and Briley, M. Validation of open-closed arm entries in an elevated plus-maze as a measure of anxiety in the rat. J. Neurosci. Methods. 14:149-167 (1985)

[48] Roig, J.L.; Fuentes, S.; Teresa, C.M.; Colomina, M.; Vicens, P. and Domingo, J.L. Aluminum, restraint stress and aging: Behavioral effects in rats after 1 and 2 years of aluminum exposure. Toxicology. 218:112-124 (2006).

[49] Schetinger, M.R.C.; Bonan, C.D.; Morsch, V.M.; Boher, D.; Valentin, L.M. and Rodrigues, S.R. Effects of aluminum sulphate on delta-aminolevulinate dehydratase from kidney, brain and liver of adult mice. Braz. J. Med. Biol. Res. 32: 761-766 (1999).

[50] Walton, J.R. A longitudinal study of rats chr.onically exposed to aluminum at human dietary levels. Neurosci. Lett. 412:29-33 (2007). 